\title{
PERBANYAKAN TUNAS Gyrinops versteegii (Gilg.) Domke
}

Shoot Multiplication of Gyrinops versteegii (Gilg.) Domke

\author{
Yelnititis \\ Balai Besar Penelitian Bioteknologi dan Pemuliaan Tanaman Hutan \\ Jl. Palagan Tentara Pelajar KM 15 Purwobinangun, Pakem, Sleman, Yogyakarta - 55582 \\ E-mail: yelnititis@yahoo.com
}

\begin{abstract}
Gyrinops versteegii (Gilg.) Domke) is a member of Thymellaceae having an important role as agarwood source that is potential to develop. Agarwood is a non timber forest product (NTFP) with a high economic value. Gyrinops versteegii (Gilg) Domke was an endemic and rare plants, however, it is cultivated on the island of Lombok. The study of shoot multiplication from single node stem and cotyledon node explants to shoot produced was conducted to find out the best method to shoot multiplication. Modification of Murashige and Skoog (MS), Gamborg (B5) dan Woody Plant Medium (WPM) supplemented with $8.0 \mathrm{~g} / \mathrm{l}$ agar, $30 \mathrm{~g} / \mathrm{l}$ sucrose and vitamin $(0.1 \mathrm{mg} / \mathrm{l}$ Thyamine, $0.5 \mathrm{mg} / \mathrm{l}$ Nicotinic acid, $0.5 \mathrm{mg} / \mathrm{l}$ Pyridoxine dan 2 $\mathrm{mg} / \mathrm{l} \mathrm{Glysin)}$ and $10 \mathrm{~g} / \mathrm{l}$ myoinositol were used as growth medium treatments. The experiment was conducted on two stages i.e. germination and shoot multiplication. Shoot induction was conducted on modification of MS medium supplemented with Benzyl Adenin (BA) 0.5; 1.0 and1.5 $\mathrm{mg} / \mathrm{l}$. The multiplication of shoot conducted on modification of MS medium, WPM and B5 medium supplemented with 0.5; 0.75 dan $1.0 \mathrm{mg} / \mathrm{l}$ Benzyl Adenin (BA). For every treatment there were ten samples (bottles) with one explants in each bottle. The observation was conducted on shoot induction percentage, number of shoot and visual performance of culture. The result showed that modified $M S+B A 0.5 \mathrm{mg} / \mathrm{l}$ was the best for shoot induction from single node stem explants with the average of 1.6 shoots on 12 weeks. The treatment of modified $M S+B A 0.75 \mathrm{mg} / \mathrm{l}$ was the best for shoot multiplication from single node stem explants with the average of 5.7 shoots on 12 weeks. The treatment of modified WPM + $0.5 \mathrm{mg} / \mathrm{l} \mathrm{BA}$ was the best for shoot multiplication from cotyledonery node explants with the average of 4.6 shoots on 12 weeks. The visual performance of shoot resulted was normal.
\end{abstract}

\section{Keywords : Gyrinops versteegii, multiplication, in vitro}

\begin{abstract}
ABSTRAK
Gyrinops versteegii (Gilg.) Domke) merupakan anggota Thymelaceae yang berperan penting sebagai jenis penghasil gaharu yang berpotensi dikembangkan. Gaharu merupakan salah satu hasil hutan bukan kayu (HHBK) yang mempunyai nilai ekonomi tinggi. Gyrinops versteegii (Gilg.) Domke termasuk jenis endemik dan langka yang tumbuh di pulau Lombok. Penelitian perbanyakan tunas dari eksplan batang satu buku dan buku kotiledon untuk produksi tunas sudah dilakukan. Penelitian ini bertujuan untuk mendapatkan metoda terbaik untuk perbanyakan tunas. Perlakuan Yang diberikan adalah medium dasar berupa modifikasi Murashige dan Skoog (MS), Gamborg (B5) dan Woody Plant Medium (WPM) yang ditambah dengan $8,0 \mathrm{gr} / 1$ agar, $30 \mathrm{gr} / 1$ sukrosa dan vitamin $\mathrm{B}(0,1 \mathrm{mg} / 1$ Thyamine, 0,5 mg/1 Nicotinic acid, 0,5 mg/l Pyridoxine dan $2 \mathrm{mg} / 1$ Glysin) dan $10 \mathrm{~g} / 1$ myoinositol. Penelitian dilakukan
\end{abstract}


dalam 2 tahap kegiatan yaitu perkecambahan biji dan perbanyakan tunas. Induksi tunas dilakukan pada perlakuan modifikasi media MS yang ditambah 0,5; 1,0 dan 1,5 mg/l Benzyl Adenine (BA). Perbanyakan tunas dilakukan pada modifikasi medium MS, B5 dan WPM yang ditambah dengan $\mathrm{BA}(0,5 ; 0,75$ dan $1,0 \mathrm{mg} / \mathrm{l})$. Masing-masing perlakuan dibuat 10 botol dan pada setiap botol terdapat 1 eksplan. Pengamatan dilakukan terhadap persentase tumbuh tunas, jumlah tunas dan penampilan biakan secara visual. Hasil penelitian menunjukkan bahwa perlakuan terbaik untuk induksi tunas dari eksplan batang satu buku adalah perlakuan modifikasi medium MS + 0,5 mg/l BA dengan rata-rata jumlah tunas sebanyak 1,6 tunas dalam 12 minggu. Perlakuan terbaik untuk perbanyakan tunas dari eksplan batang satu buku adalah perlakuan modifikasi media $\mathrm{MS}+0,75 \mathrm{mg} / \mathrm{l} \mathrm{BA}$, dengan jumlah rata-rata tunas sebanyak 5,7 tunas dalam 12 minggu. Perlakuan terbaik untuk perbanyakan tunas dari eksplan buku kotiledon adalah modifikasi media WPM $+0,5 \mathrm{mg} / \mathrm{l} \mathrm{BA}$, dengan jumlah tunas sebanyak 4,6 tunas dalam 12 minggu. Tunas yang dihasilkan mempunyai penampilan visual normal.

\section{Kata kunci : Gyrinops versteegii, perbanyakan, in vitro}

\section{PENDAHULUAN}

Gyrinops versteegii (Gilg.) Domke) merupakan anggota Thymelaceae dan termasuk salah satu jenis penghasil gaharu yang tumbuh secara alami di pulau Lombok dan Sumbawa, Flores, Sumba dan Timor yang berpotensi untuk dikembangkan (Surata, 2004). Gaharu adalah salah satu komoditas hasil hutan bukan kayu (HHBK) yang sangat istimewa karena harganya yang tinggi. Gaharu memiliki bentuk, aroma dan warna yang khas serta memiliki kadar damar yang tinggi, dapat digunakan untuk pengasapan, bahan parfum (CITES 2003), pewangi ruangan, sabun, obat dan sampo (Sumarna, 2002). Menurut Surata (2006) bentuk produk gaharu yang diperdagangkan bermacammacam antara lain kayu bongkahan, chip, serbuk dan minyak gaharu. Gaharu dari $G$ versteegii (Gilg). Domke lebih disukai oleh konsumen karena karakteristiknya berbeda dari jenis lain (Parman dan Mulyaningsih, 2001). Gubal gaharu dengan kualitas super dapat mencapai harga Rp. 10 - Rp. 15 juta/ $\mathrm{kg}$. Indonesia merupakan negara pengekspor utama produk gaharu di dunia. Dari tahun ketahun produksi gaharu secara nasional semakin menurun. Biro Pusat Statistik (2000) menyatakan bahwa ekspor gaharu Indonesia pada tahun 1995 sebanyak 400 ton, tahun 1996 sebanyak 300 ton, tahun 1997 sebanyak 270 ton dan menurun menjadi 150 ton pada tahun 1998. Selanjutnya menurut Wiguna (2006) kuota ekspor gaharu Indonesia pada tahun 2000 untuk

Aquilaria malaccensis sebanyak 225 ton tetapi menurun menjadi 50 ton pada tahun 2005 . 
Eksploitasi jenis penghasil gaharu yang berlangsung terus menerus mengakibatkan sebagian besar populasi gaharu menjadi rusak dan terancam punah. Hal ini disebabkan karena kurangnya pengetahuan dalam menentukan ada atau tidaknya gaharu pada pohon penghasil gaharu yang ditebang. Akibat tingginya intensitas pemungutan dan menurunnya daya dukung kawasan hutan, produksi gaharu alam terus menurun sehingga tahun 1994 jenis penghasil gaharu A. malaccensis dimasukkan ke dalam APPENDIX II CITES yaitu keberadaannya yang sudah terancam punah. Menurut Mogea et al., (2001), Gyrinops versteegii (Gilg.) Domke) termasuk kedalam daftar empat puluh jenis tumbuhan langka Indonesia. Selanjutnya Hadi et al., (2011) menyatakan bahwa $G$. versteegii merupakan jenis endemik dan termasuk tanaman langka yang tumbuh di pulau Lombok.

Perbanyakan Gyrinops versteegii dapat dilakukan secara generatif dengan menggunakan biji. Menurut Zubaidi dan Farida (2008) penyediaan bibit merupakan kendala dalam budidaya Gyrinops. Buah yang jatuh dibawah tegakan pohon induk mengalami perkecambahan dan petani umumnya mengambil anakan tersebut untuk dijadikan bibit namun anakan yang dicabut banyak mengalami kematian setelah ditanam. Selain itu buah yang dihasilkan tidak semuanya dapat berkecambah. Perbanyakan tanaman secara vegetatif konvensional untuk jenis ini belum banyak dilaporkan demikian pula dengan perbanyakan vegetatif melalui kultur jaringan sehingga penelitian tentang perbanyakan tunas sebagai tahap awal dalam penyediaan bibit menjadi penting untuk dilakukan.

Kultur jaringan merupakan salah satu teknik yang banyak digunakan untuk mengatasi masalah kebutuhan bibit. Berbagai jenis eksplan dapat digunakan antara lain batang satu buku, potongan daun, akar, embrio, buah dan lain-lain. Pemilihan media dan zat pengatur tumbuh yang cocok sangat menentukan keberhasilan. Media dasar Murashige dan Skoog (MS) merupakan media yang paling banyak digunakan dalam kultur jaringan. Media MS mempunyai kandungan hara yang lebih tinggi dibandingkan dengan media dasar lain terutama KNO3 dan $\mathrm{NH} 4 \mathrm{NO} 3$ sebagai sumber nitrogen. Nitrogen merupakan faktor utama dalam memacu morfogenesis secara in vitro. Menurut Gunawan (1987) walaupun 
unsur-unsur makro dalam media MS dibuat untuk kultur kalus tembakau tetapi komposisi media MS pada umumnya juga mendukung kultur jaringan tanaman lainnya. Selanjutnya Ammirato (1983) menyatakan bahwa bentuk nitrogen reduksi sangat penting untuk inisiasi dan perkembangan. Demikian juga dengan Adkins et al., (2002), menyatakan bahwa kandungan amonium nitrat yang tinggi berfungsi dalam mendorong diferensiasi sel. Selain media MS juga banyak digunakan media dasar lain antara media dasar WPM (Woody Plant Medium) yang khusus digunakan untuk tanaman berkayu (Tricoli et al., 1985) dan media B5 (Gamborg et al., 1968).

Keberhasilan dalam kultur jaringan dipengaruhi oleh berbagai faktor antara lain zat pengatur tumbuh tanaman. Gunawan (1987) menyatakan bahwa proses pembelahan sel, proliferasi kalus dan morfogenesis di dalam kultur jaringan dipengaruhi oleh sitokinin. Benzyl Adenine (BA) dan kinetin termasuk kelompok sitokinin yang banyak digunakan dalam perbanyakan, organogenesis dan embriogenesis (Zhang et al., 2003).

Berdasarkan hal diatas maka dilakukan penelitian perbanyakan tunas dengan menggunakan eksplan yang berbeda.
Penelitian bertujuan untuk mendapatkan metode perbanyakan tunas in vitro terbaik pada tanaman Gyrinops versteegi.

\section{BAHAN DAN METODE}

Penelitian dilaksanakan di Laboratorium Kultur Jaringan Balai Besar Penelitian Bioteknologi dan Pemuliaan Tanaman Hutan Yogyakarta dari bulan Januari 2012 sampai bulan Februari 2013.

Bagian tanaman yang digunakan sebagai sumber eksplan adalah buah yang diambil dari 15 pohon (15 famili) induk (Tabel 1) asal Lombok Barat dan Lombok Tengah serta potongan batang satu buku (buku kedua dari atas) dengan ukuran $2-3$ cm yang diambil dari anakan umur 3 tahun. Masing-masing famili B1, B2, R1 dan K1, K2, K3, K4, K5 dan K 6 dikecambahkan biji sebanyak 50 buah sedangkan untuk B3, R2, R3, R4, R5 dan R6 dikecambahkan biji sebanyak 100 buah. Modifikasi media dasar Murashige dan Skoog (MS) yang dan diperkaya dengan $30 \mathrm{gr} / 1$ sukrosa dan $8 \mathrm{gr} / \mathrm{l}$ agar dan vitamin B dijadikan sebagai media tumbuh. Penelitian dilakukan dalam 2 tahap kegiatan yaitu perkecambahan biji dan perbanyakan tunas. 


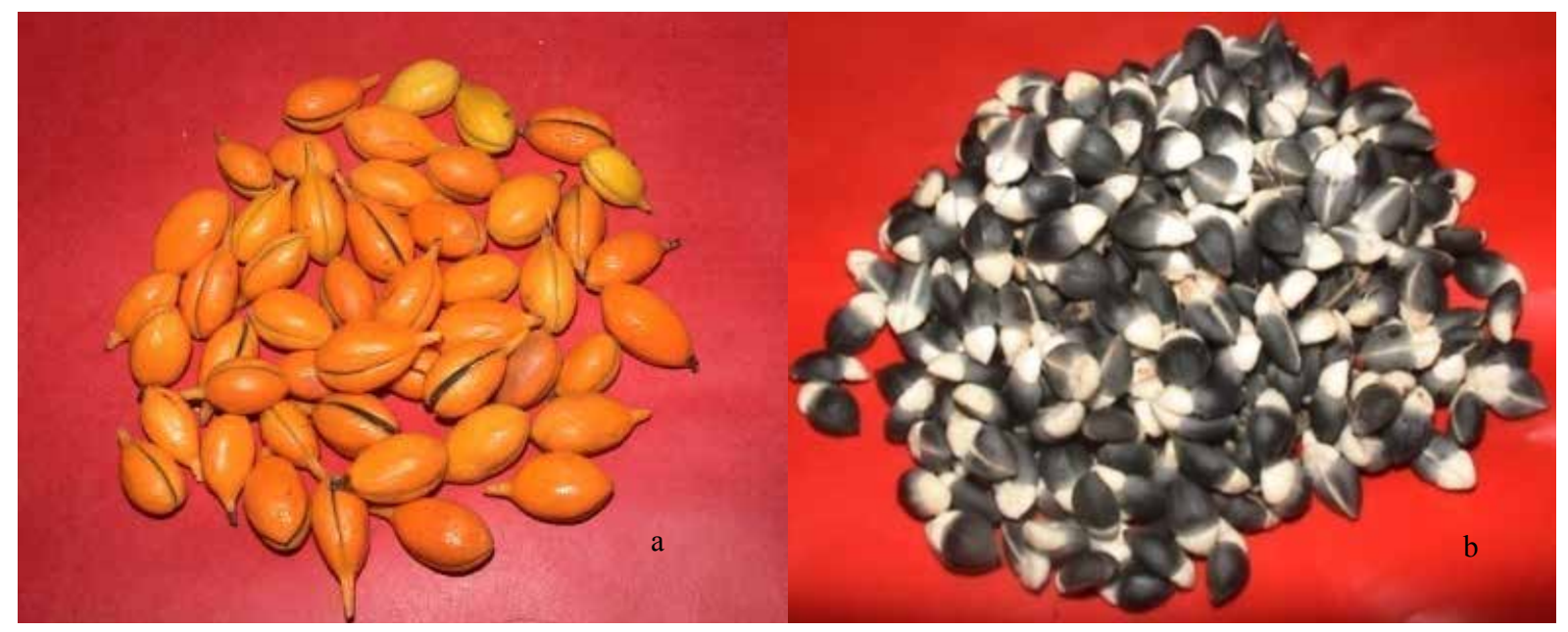

Gambar 1. Buah Gyrinops versteegii dari pohon induk (a) dan Biji dengan kulit biji (b)

\section{A. Perkecambahan biji}

Perkecambahan biji dilakukan secara in vitro. Buah (Gambar 1a) yang diambil dari pohon induk dicuci bersih lalu kulit buahnya dibuang dan diambil bijinya (Gambar 1b).

Kemudian biji disterilisasi dengan menggunakan alkohol $70 \%$, bayclin 20\% dan $10 \%$ dan dibilas dengan air steril sebanyak 3 kali. Kulit ari biji dibuang, kemudian bijinya direndam menggunakan larutan betadin selama 10 menit, lalu biji (Gambar 2a) dikecambahkan pada media MS 0 (Gambar 2b) atau tanpa penambahan zat pengatur tumbuh. Pengamatan dilakukan selama 8 minggu terhadap jumlah biji yang berkecambah dan visual biakan yang dihasilkan.
Tabel 1. Famili, lokasi pohon induk dan jumlah biji yang dikecambahkan.

\begin{tabular}{clc}
\hline Famili & Lokasi pohon induk & $\begin{array}{c}\text { Jumlah biji } \\
\text { dikecam- } \\
\text { bahkan }\end{array}$ \\
\hline B 1 & Sepakek, Lombok Tengah & 50 \\
B 2 & Sepakek, Lombok Tengah & 50 \\
B 3 & Sepakek, Lombok Tengah & 100 \\
R 1 & Rarung, Lombok Tengah & 50 \\
R 2 & Rarung, Lombok Tengah & 100 \\
R 3 & Rarung, Lombok Tengah & 100 \\
R 4 & Rarung, Lombok Tengah & 100 \\
R 5 & Rarung, Lombok Tengah & 100 \\
R 6 & Rarung, Lombok Tengah & 100 \\
K 1 & Karya Jaya, Lombok Barat & 50 \\
K 2 & Karya Jaya, Lombok Barat & 50 \\
K 3 & Karya Jaya, Lombok Barat & 50 \\
K 4 & Karya Jaya, Lombok Barat & 50 \\
K 5 & Karya Jaya, Lombok Barat & 50 \\
K 6 & Karya Jaya, Lombok Barat & 50 \\
\hline
\end{tabular}

\section{B. Perbanyakan tunas}

\section{Induksi tunas}

Penelitian perbanyakan tunas diawali dengan tahap induksi tunas. Eksplan yang digunakan adalah batang satu buku dari tanaman muda umur 3 tahun. Media dasar 
MS digunakan pada tahap induksi tunas. Sebagai perlakuan digunakan Benzyl Adenin (BA) dari kelompok sitokinin dengan konsentrasi 0,$5 ; 1,0$ dan 1,5 mg/l. Setiap perlakuan terdiri dari 10 botol dan setiap botol terdapat 1 eksplan. Pengamatan dilakukan selama 12 minggu terhadap jumlah tunas dan penampilan biakan secara visual.

\section{Perbanyakan tunas}

Penelitian perbanyakan tunas dilakukan dalam dua seri kegiatan yaitu dengan menggunakan eksplan batang satu buku dan buku kotiledon dari kecambah in vitro dengan ukuran $2 \mathrm{~cm}$. Eksplan ditumbuhkan selama 12 minggu pada modifikasi media MS (Murashige dan Skoog, 1962), WPM (Llyod dan Crown, 1981) dan B5 (Gamborg et al., 1968) yang ditambah dengan 0,$5 ; 0,75 \mathrm{mg} / 1 \mathrm{BA}$. Pengamatan dilakukan terhadap persentase tumbuh tunas, jumlah tunas dan penampilan biakan secara visual. Data kuantitatif yang diperoleh dihitung rata-rata dan standar deviasinya serta data kualitatif dianalisis secara deskriptif.

\section{HASIL DAN PEMBAHASAN}

\section{A. Perkecambahan biji}

Hasil penelitian menunjukkan bahwa pada tahap perkecambahan biji (Gambar 2b) dari 15 famili yang dikecambahkan diperoleh 4 famili yang berkecambah yaitu famili R1, R2,R4 dan B3 (Tabel 2) sedangkan 11 famili lainnya tidak memperlihatkan respon sama sekali walaupun sudah dikecambahkan selama 12 bulan. Hal ini disebabkan karena adanya kontaminasi eksplan setelah penanaman. Selain itu juga disebabkan karena tidak semua biji yang dikecambahkan mempunyai embrio yang sempurna antara lain disebabkan buah yang dijadikan sebagai eksplan belum masak secara fisiologis. Menurut Surata (2006) buah masak fisiologis mempunyai ciri-ciri kulit buah yang berwarna hijau kekuningan dan cangkang buah belum merekah.

Biji yang dikecambahkan mulai memperlihatkan respon antara 5 sampai 12 hari setelah ditumbuhkan pada media tumbuh. Perbedaan ini diduga lebih disebabkan karena perbedaan umur fisiologi dari biji yang dikecambahkan walaupun berasal dari pohon induk yang sama. 
Tabel 2. Jumlah biji yang berkecambah

\begin{tabular}{cccc}
\hline Sumber biji & $\begin{array}{c}\text { Jumlah } \\
\text { biji } \\
\text { berke- } \\
\text { cambah }\end{array}$ & $\begin{array}{c}\text { \%-ase } \\
\text { biji } \\
\text { berke- } \\
\text { cambah }\end{array}$ & Visual biakan \\
\hline $\begin{array}{c}\text { Lombok } \\
\text { Tengah 1 (R1) } \\
\text { Lombok }\end{array}$ & 11 & 22 & $\begin{array}{c}\text { Normal, } \\
\text { hijau segar } \\
\text { Tengah 2 (R2) } \\
\text { Lombok }\end{array}$ \\
$\begin{array}{c}\text { Tengah 3 (R4) } \\
\text { Lombok }\end{array}$ & 75 & 75 & $\begin{array}{c}\text { Normal, hijau } \\
\text { segar }\end{array}$ \\
Tengah 4 (B3) & 67 & 67 & $\begin{array}{c}\text { Normal, hijau } \\
\text { segar } \\
\text { Normal, hijau } \\
\text { segar }\end{array}$ \\
\hline
\end{tabular}

Dari 4 famili yang berkecambah diperoleh biakan masing-masing sebanyak 11, 75, 75 dan 67 buah (Tabel 2) dengan persentase masing-masing sebanyak 22 $\%, 75 \%, 75 \%$ dan $67 \%$ dari total jumlah biji yang dikecambahkan. Biakan yang dihasilkan mempunyai penampilan normal dengan tinggi antara 6,0-8,0 $\mathrm{cm}$ (Gambar 2c) dalam jangka waktu 8 minggu. Bagian buku kotiledon dari kecambah in vitro ini untuk selanjutnya digunakan sebagai eksplan pada tahap perbanyakan tunas.

\section{B. Perbanyakan tunas}

1. Induksi tunas

Kegiatan pada tahap perbanyakan tunas diawali dengan tahap induksi tunas. Induksi tunas dilakukan dengan menggunakan eksplan batang satu buku dari anakan / seedling umur 3 tahun. Hasil penelitian menunjukkan bahwa penggunaan zat pengatur tumbuh BA pada semua konsentrasi dapat merangsang eksplan membentuk tunas. Persentase eksplan yang menghasilkan tunas dari semua perlakuan BA yang digunakan adalah $100 \%$. Jumlah tunas yang dihasilkan pada tahap induksi antara $1-2$ tunas dan kegiatan subkultur berulang dapat meningkatkan jumlah tunas.

Dari 3 perlakuan BA yang diuji, perlakuan modifikasi media MS + 0,5 mg/1 BA merupakan perlakuan yang terbaik terhadap induksi dan penampilan visual biakan yang dihasilkan. Walaupun dengan konsentrasi yang rendah, BA dapat mengatur

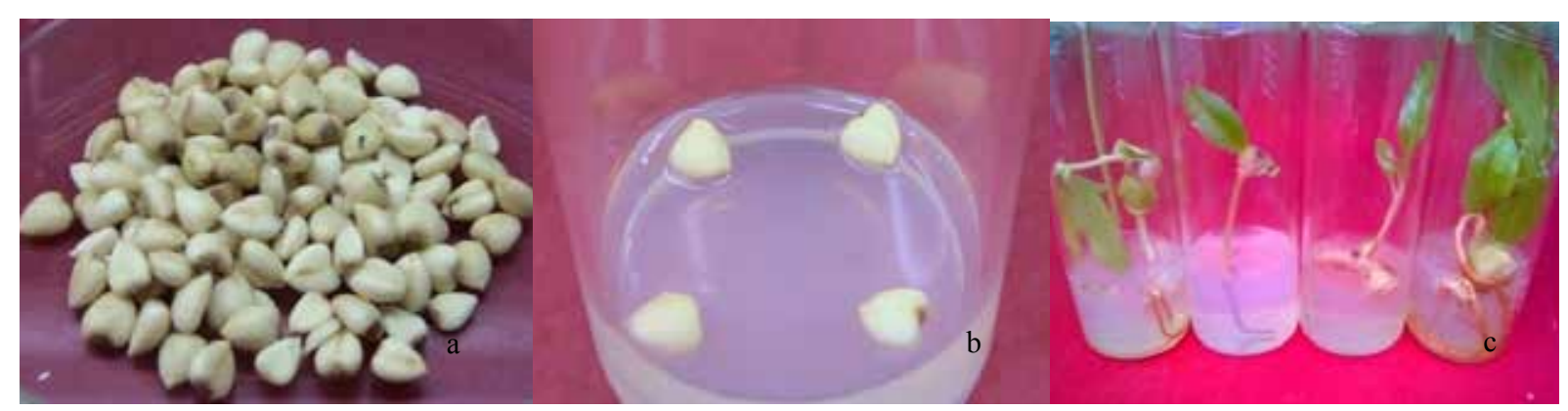

Gambar 2. Biji tanpa kulit ari biji (a), perkecambahkan biji pada media MS 0 (kontrol) (b) dan biakan hasil perkecambahan (c) 


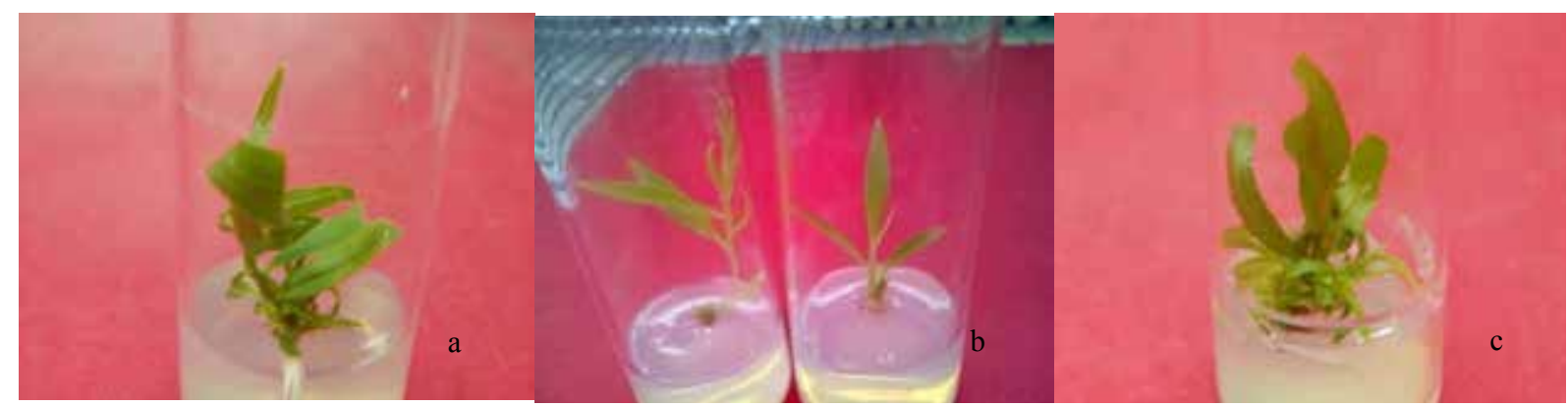

Gambar 3. Tunas hasil induksi dari eksplan batang satu buku, b. Tunas hasil perbanyakan dari eksplan buku kotiledon dan c. Tunas hasil perbanyakan dari eksplan batang satu buku (c)

proses fisiologis tumbuhan. Menurut George (1993) BA merupakan zat pengatur tumbuh kelompok sitokinin yang umum digunakan dalam perbanyakan in vitro untuk menstimulasi pembelahan sel dan multiplikasi tunas. Rata-rata jumlah tunas yang dihasilkan pada semua perlakuan yang diuji pada tahap induksi (Gambar 3a) adalah sebanyak 1,6 tunas (Tabel 3) dalam 12 minggu.

Tabel 3. Jumlah tunas terbentuk pada tahap induksi

\begin{tabular}{ccl}
\hline $\begin{array}{c}\text { Perlakuan } \\
(\mathrm{mg} / \mathrm{l})\end{array}$ & $\begin{array}{c}\text { Rerata } \\
\text { jumlah } \\
\text { tunas } \\
\text { terbentuk }\end{array}$ & Visual biakan \\
\hline MS + BA 0,5 & 1,6 & $\begin{array}{l}\text { Hijau, ukuran } \\
\text { sedang }\end{array}$ \\
+ BA 1,0 & 1,0 & $\begin{array}{l}\text { Hijau, ukuran } \\
\text { pendek }\end{array}$ \\
+ BA 1,5 & 1,0 & $\begin{array}{l}\text { Hijau, ukuran } \\
\text { pendek }\end{array}$ \\
\hline
\end{tabular}

Tunas yang dihasilkan dari perlakuan ini mempunyai ukuran tinggi normal dengan rata-rata tinggi $6,1 \mathrm{~cm}$, sedangkan tunas yang dihasilkan dari perlakuan 1,0 dan 1,5 mg/l BA berukuran lebih pendek dengan tinggi antara $0,5-2,7 \mathrm{~cm}$ dan ukuran batang yang lebih besar atau diameter lebih dari $2 \mathrm{~mm}$. Hal ini diduga disebabkan karena konsentrasi BA pada 1,0 dan 1,5 mg/1 sudah bersifat menghambat pertumbuhan tunas kearah pemanjangan untuk jenis Gyrinops. Teo (1992) menyatakan bahwa penggunaan BA dengan konsentrasi lebih tinggi dapat merangsang proliferasi tunas tetapi tunas yang dihasilkan berukuran lebih kecil dan penampilan visual morfologi yang berbeda. Tunas yang mempunyai penampilan normal dari perlakuan $0,5 \mathrm{mg} / 1$ dijadikan sebagai eksplan pada tahap perbanyakan tunas.

\section{Perbanyakan tunas}

Pada tahap perbanyakan tunas digunakan eksplan buku kotiledon dari biakan hasil perkecambahan secara in vitro dan batang satu buku dari biakan steril yang diperoleh pada tahap induksi. Dari 
dua sumber eksplan tersebut diperoleh hasil sebagai berikut :

\section{a. Eksplan buku kotiledon}

Hasil penelitian menunjukkan bahwa eksplan buku kotiledon yang ditumbuhkan pada perlakuan modifikasi media MS, WPM dan B5 yang ditambah dengan BA 0,5 dan 0,75 mg/1 dapat membentuk tunas. Menurut Kulkarni et al., (2000) dari dua jenis sitokinin yang digunakan, BA merupakan jenis sitokinin yang memberikan hasil terbaik untuk proliferasi tunas dari eksplan buku kotiledon pada tanaman Withania somnifora. Tunas mulai terbentuk antara 7 sampai 18 hari setelah ditumbuhkan pada media tumbuh. Hasil yang hampir sama dengan penelitian Haris et al., (2013) menyatakan bahwa rata-rata induksi tunas pada tanaman cengkeh diperoleh paling cepat terjadi 12 hari setelah ditumbuhkan. Hal yang sama juga dinyatakan Kulkarni et al., (2000) bahwa pembentukan tunas dari eksplan buku kotiledon tanaman Withania somnifora terjadi setelah 12 hari dikulturkan pada media MS yang ditambah dengan 1,0 $\mathrm{mg} / 1 \mathrm{BA}$.

Dari semua perlakuan yang digunakan, perlakuan modifikasi media WPM $+0,5$ mg/l BA merupakan perlakuan paling cepat membentuk tunas yaitu 7 hari setelah ditumbuhkan. Hal ini diduga disebabkan karena eksplan yang digunakan berasal dari jaringan yang masih sangat muda yaitu dari kecambah yang diperoleh secara in vitro yang berumur 4 minggu. Medium WPM dengan kandungan hara yang lebih rendah dari medium MS diduga lebih cocok untuk merangsang pertumbuhan awal dari eksplan yang ditumbuhkan.

Dari tiga jenis media yang digunakan, perlakuan modifikasi media WPM $+0,5$ mg/l BA juga merupakan perlakuan terbaik untuk perbanyakan tunas (Tabel 4). Ratarata jumlah tunas yang dihasilkan dari perlakuan ini adalah 4,6 tunas dalam 12

Tabel 4. Jumlah tunas dari perlakuan BA

\begin{tabular}{cccc}
\hline $\begin{array}{c}\text { Perlakuan } \\
(\mathrm{mg} / \mathrm{l})\end{array}$ & $\begin{array}{c}\text { Wkt induksi tunas } \\
\text { (hari) }\end{array}$ & $\begin{array}{c}\text { Rerata jml tunas } \\
\text { terbentuk }\end{array}$ & Visual biakan \\
\hline MS + BA 0,5 & 10 & 2,6 & Hijau, ukuran sedang \\
+ BA 0,75 & 12 & 1 & Hijau, ukuran sedang \\
WPM + BA 0,5 & 5 & 4,6 & Hijau, ukuran sedang \\
+ BA 0,75 & 9 & 2 & Hijau, ukuran sedang \\
B5 + BA 0,5 & 15 & 3 & Hijau, ukuran sedang \\
+ BA 0,75 & 18 & 2 & Hijau, ukuran sedang \\
\hline
\end{tabular}


minggu (Gambar 3b). Menurut Giri et al., (2004) keberhasilan dalam perbanyakan tanaman melalui kultur jaringan tergantung pada jenis medium kultur, spesies, kualitas eksplan, umur tanaman sumber eksplan, zat pengatur tumbuh tanaman dan interaksi antara semua faktor-faktor tersebut. Hasil yang sama dengan penelitian Te-chato dan Lim, (1999) menunjukkan bahwa penggunaan $22 \mu \mathrm{M}$ BA pada media MS atau WPM dihasilkan tunas antara 2 sampai 50 tunas tanpa adanya pembentukan kalus pada tanaman manggis. Menurut Gunawan (1987) tingginya respon jaringan untuk tumbuh disebabkan oleh penambahan zat pengatur tumbuh sitokinin dan atau auksin pada media tersebut yang mampu merubah kandungan hormon endogen dari sel dan jaringan yang ditumbuhkan. Dari perlakuan yang sama Azwin dkk. (2006) mendapatkan tunas sebanyak 5,67 pada tanaman A. malaccensis.

b. Eksplan batang satu buku.

Penggunaan eksplan batang satu buku dari biakan steril memberikan kemudahan dalam mendapatkan eksplan sehingga tidak perlu dilakukan sterilisasi lagi. Hasil penelitian menunjukkan bahwa semua eksplan yang ditumbuhkan memberikan respon dalam tunas. Pierik (1987) menyatakan bahwa BA banyak digunakan untuk memacu inisiasi dan proliferasi tunas, mendorong pembelahan sel dan menginduksi tunas adventif.

Dari tiga jenis media yang digunakan, perlakuan modifikasi media MS + 0,75 mg/l BA merupakan perlakuan terbaik untuk perbanyakan tunas dari eksplan batang satu buku. Jumlah tunas yang dihasilkan (Gambar 3c) dari perlakuan ini adalah 5,7 tunas (Gambar 4) dalam 12 minggu. Menurut Devy dan Sutanto (1992) penggunaan sitokinin secara tunggal maupun dikombinasikan dengan auksin berperan dalam menginduksi dan penggandaan tunas. Diego et al., (2008) menyatakan bahwa penggunaan $25 \mu \mathrm{M}$ BA pada media menghasilkan jumlah tunas paling banyak yaitu 61,58 \% dari eksplan yang dikulturkan pada tanaman Pinus pinaster dewasa. Hasil yang berbeda dari penelitian Sarmast et al., (2009) melaporkan bahwa penggunaan kombinasi $12 \mu \mathrm{M}$ BA dan $3 \mu \mathrm{M}$ NAA menghasilkan tunas sebanyak 0,6 pada tanaman Araucaria excels $\mathrm{R}$. Br. var glauca. Selanjutnya Haris et al., (2013) menyatakan bahwa penggunaan BA dengan konsentrasi relatif tinggi yaitu $6,0 \mathrm{mg} / \mathrm{l}$ yang dikombinasikan dengan NAA $0,5 \mathrm{mg} / 1$ pada media MS dapat menghasilkan 3 tunas dalam 
8 minggu pada tanaman cengkeh. Demikian juga dengan Phulwaria et al., (2011) yang mendapatkan tunas sebanyak 23,1 dari perlakuan kombinasi $1,11 \mu \mathrm{M} \mathrm{BA}+1,16$ $\mu \mathrm{M}$ kin $+0,54 \mu \mathrm{M}$ NAA dari eksplan yang berasal dari tanaman tua Salvadora persica.

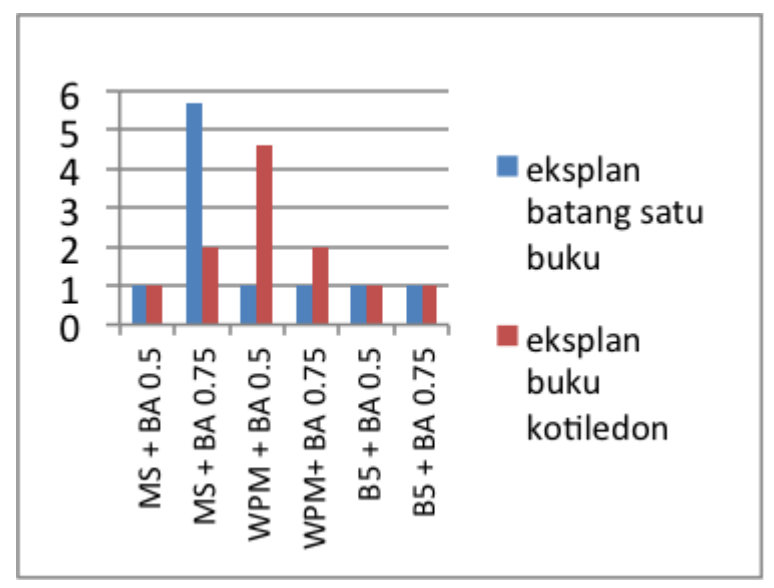

Gambar 4. Jumlah tunas pada perlakuan media dan BA berbeda

Perbedaan sumber eksplan yang digunakan menghasilkan tunas dengan visual yang juga berbeda. Dari Tabel 3 dapat dilihat bahwa semua tunas yang dihasilkan dari eksplan batang satu buku pada semua jenis media yang digunakan mempunyai batang yang berukuran sedang dan tegar dengan daun yang berwarna hijau tua, sedangkan tunas yang dihasilkan dari eksplan buku kotiledon mempunyai batang yang berukuran kecil dan berwarna hijau muda serta memperlihatkan pertumbuhan tunas ke arah pemanjangan yang lebih cepat dibandingkan dengan eksplan batang satu buku. Namun demikian tunas yang yang dihasilkan dari dua sumber eksplan adalah normal.

\section{KESIMPULAN}

Perlakuan modifikasi media MS + 0,5 mg/l BA merupakan perlakuan terbaik untuk induksi tunas dari eksplan batang satu buku. Perlakuan modifikasi media MS + 0,75 mg/1 BA merupakan perlakuan terbaik untuk perbanyakan tunas dengan rata-rata jumlah tunas sebanyak 5,7. Perlakuan media WPM + BA 0,5 mg/l merupakan perlakuan terbaik untuk perbanyakan tunas dari buku kotiledon dengan jumlah tunas sebanyak 4,6 dalam 12 minggu.

Tabel 5. Visual biakan dari perlakuan media berbeda

\begin{tabular}{llc}
\hline \multicolumn{1}{c}{ Perlakuan (mg/l) } & \multicolumn{2}{c}{ Visual biakan } \\
\hline MS + BA 0,5 & Eksplan batang satu buku & Eksplan buku kotiledon \\
MS + BA 0,75 & Normal, pendek, hijau tua & Normal, tinggi, hijau muda \\
WPM + BA 0,5 & Normal, sedang, hijau tua & Normal, tinggi, hijau muda \\
WPM+ BA 0,75 & Normal, sedang, hijau tua & Normal, tinggi, hijau muda \\
B5 + BA 0,5 & Normal, sedang, hijau tua & Normal, tinggi, hijau muda \\
B5 + BA 0,75 & Normal, sedang, hijau tua & Normal, tinggi, hijau muda \\
\hline
\end{tabular}




\section{DAFTAR PUSTAKA}

Adkins, S.W; A.L. Adkins; C.M. Ramage \& R.R. Williams. 2002. In vitro ecology Smodification of headspace and medium conditions can optimize tissue and plant development. In Taji, A.R. Williams (eds). The importance of plant tissue culture and biotechnology in plant sciences. University of New England Unit. Australia, pp. 55 -77.

Ammirato, P.V. 1983. Embryogenesis. In Evans, D.A., W.R. Sharp, P.V. Ammirato \& Y. Yamada. (Eds.). Handbook of Plant Cell Culture $1: 82-123$.

Azwin, I.Z. Siregar \& Supriyanto. 2006. Penggunaan BAP dan thidiazuron untuk perbanyakan tanaman gaharu (Aquilaria malaccensis Lamk.). Media Konservasi $X I(3): 98-104$.

Biro Pusat Statistik. 2000. Statistik Indonesia 1990 - 2000. Biro Pusat Statistik. Jakarta.

CITES. 2003. Review of significant trade Aquilaria malaccensis. CITES Document no PC14 Doc. 9.2.2. Annex 2.

CITES. 2004. Convention on International trade in endangered species of wild fauna and flora: Amandements to Appendices I and II of CITES Thirteenth Meeting of the Conference of the Parties 3-14 Oct. Bangkok. Thailand.

Devy, NS \& A. Sutanto. 1992. Pengaruh komposisi media dan zat pengatur tumbuh terhadap perbanyakan batang bawah apel asal Bromo secara in vitro. J. Hort. 2 (4) : $13-20$.

Diego, N.D, I.A. Montalban, E.F. de Larrinoa \& P. Moncalean. 2008. In vitro regeneration of Pinus pinaster adult trees. Can. J. For. Res. $38: 2607-2615$.

Gamborg, O.L.; R.A. Miller \& K. Ojima. 1968. Nutrient requirements of suspension cultures of soybean root cells. Exp. Cell Res. $50: 151-158$.

George, E.F. 1993. Plant propagation by tissue culture. Part I. The technology. Edington, Wilts, Exegetics Ltd, BA 134QG, England. $1361 \mathrm{p}$.

Giri, C.C; B. Shyamkumar \& C. Anjaneyulu. 2004. Progress in tissue culture, genetic transformation and applications of biotechnology to trees: an overview. Trees $18: 115-135$.
Gunawan, L.W. 1987. Teknik kultur jaringan tumbuhan. PAU. IPB. Bogor.

Hadi, S; H. Muliasari; N.S. Sukma \& P.E.W. Ratnaningsih. 2011. Phytochemical screening and antibacterial testing of gaharu trees (Gyrinops versteegii (Gilg.) Domke) from Lombok Island. Proceeding of the 2th International Seminar on Chemistry. pp. $79-82$. Jatinangor. 24 - 25 November.

Haris, A, Z. Basri \& M.U. Bustami. 2013. Inisiasi tunas cengkeh (Syzigium aromaticum L.) dengan berbagai konsentrasi BAP secara in vitro. e-J Agrotekbis 1 (4) : $307-313$.

Kulkarni, AA, SR. Thengane \& KV. Krishnamurthy. 2000. Direct shoot regeneration from node, internode, hypocotyl and embryo explants of Withania somnifera. Plant Cell Tissue Organ Cult 62:203-209.

Llyod, G. \& B.H. Mc. Crown. 1981. Woody Plant Medium : A mineral nutrient formulation for microculture of woody plant species. Hort. Sci. $16: 89-96$.

Mayerni, R; N. Herawati \& Syazwana. 2011. Pengaruh konsentrasi NAA terhadap pertumbuhan dan perkembangan plantlet kina (Chincona succirubra Pavon) pada subkultur ke IV. Jerami 4 (1) : 17 -23.

Mogea, J.P; J. Gandawidjaya; H. Wiriadinata; R.E. Nasution \& Irawati. 2001. Daftar empat puluh jenis tumbuhan langka. Tumbuhan Langka Indonesia. Puslitbang Biologi. LIPI. Bogor.

Parman, S. \& T. Mulyaningsih. 2001. Teknologi pembudidayaan tanaman gaharu. Makalah disampaikan pada Lokakarya Pengembangan Tanaman Gaharu. Mataram 4 - 5 September. Dirjen Rehabilitasi Lahan dan Perhutanan Sosial. Jakarta

Phulwaria, M; K. Ram; P. Gahlot \& N.S. Shekhawat. 2011. Micropropagation of Salvadora persica - a tree of arid horticultura and forestry. New Forests $42: 317-327$.

Pierik, R.L.M. 1987. In vitro culture of higher plants. Martinus N.J. Hoff Publisher. London. 344 pp.

Santosa, J; N.T. Mathius; T. Sastraprawira; U. Suryatmana \& D. Saodah. 2004. Perbanyakan tanaman kina (Chincona ledgerianan) Moens dan C. succirubra 
melalui penggandaan tunas aksiler. http://www.google.co.id.

Sarmast, M.K, H. Salehi \& M.Khosh-Khui. 2009. Using plagiotropic shoot explants in tissue culture of Araucaria excelsa $\mathrm{R}$. Br. var glauca. Advances in Environmental Biology 3 (2) : 191 - 194.

Sumarna, Y. 2002. Budidaya gaharu. Seri Agribisnis. Jakarta. Penebar Swadaya.

Surata, I.K. 2004. Laporan Penelitian Teknik Budidaya Gaharu. Laporan Penelitian Proyek Balai Penelitian Kehutanan Kupang ( tidak dipublikasikan).

Surata, I.K. 2006. Teknik budidaya dan produksi gaharu. Prosiding Ekspose/ diskusi Hasil-hasil penelitian Balai Litbang Kehutanan Bali - Nusa Tenggara. Kupang. 12 Desember. Hal $39-57$.
Te-chato, S and M. Lim. 1999. Plant regeneration of mangosteen via nodular callus formation, Plant Cell, Tissue and Organ Culture 59: 89-93.

Tricoli D.M; C.A. Maynard and A.P. Andrew. 1985. Tissue culture of propagation of mature tree of Prunus serotia (Ebrh. I) establishment, multiplication and rooting in vitro. Forest Science $31: 201$ -208 .

Wiguna, I. 2006. Tinggi permintaan terganjal pasokan. Trubus Edisi No. 438. Mei.

Zhang, H., K.J. Horgan, P.H.S. Reynolds \& P.E. Jameson. 2003. Cytokinins and buds morphology in Pinus radiata. Physiol. Plant. $117: 264-269$.

Zubaidi, A dan N. Farida. 2008. Pertumbuhan bibit gaharu pada beberapa jenis naungan. CropAgro 1 (2) : $92-96$. 